DOI: https://doi.org/10.32839/2304-5809/2019-3-67-66

UDC 378:811.111

Shevchenko Mariana

National Technical University of Ukraine

"Igor Sikorsky Kyiv Polytechnic Institute"

\title{
ANALYSIS OF AUTHENTIC VIDEOS AS STUDY-ENHANCING AIDS IN ENGLISH FOR SPECIFIC PURPOSES LESSONS AT TECHNICAL UNIVERSITIES
}

Summary. The analysis of authentic videos as study-enhancing aids in ESP lessons at technical universities is done in the article. Technical students are often taught English for Specific Purposes (ESP). Therefore, the meaning of ESP, its relation to English as a Foreign Language (EFL) and English for Science and Technology, and the main features of ESP teaching at technical universities are clarified in the paper. In addition to that, the importance of audiovisual aids and their authenticity in ESP lessons is clarified. Among the media, the most authentic and diverse are films, series, and programmes. Thus, the advantages of authentic English videos and the possible disadvantages of their incorrect implementation in the study process are specified. Following the analysis of the role of authentic videos in ESP lessons, the experimental verification of the studied issue with $3^{\text {rd }}$-year students-engineers and the results are provided.

Keywords: authentic, video, aids, ESP, English for Specific Purposes, EFL, English as a Foreign Language, lesson, teaching, students, study, film, movie, technical university.

Шевченко М.В. Національний технічний університет України «Київський політехнічний інститут імені Ігоря Сікорського»

\section{АНАЛІЗ АВТЕНТИЧНИХ ВІДЕО ЯК ЗАСОБІВ, ЩО ПОКРАЩУЮТЬ НАВЧАННЯ НА ЗАНЯТТЯХ ІЗ АНГЛІЙСЬКОЇ МОВИ ТЕХНІЧНОГО СПРЯМУВАННЯ В ТЕХНІЧНИХ УНІВЕРСИТЕТАХ}

\begin{abstract}
Анотація. Використання відеозаписів на заняттях із англійської мови робить викладання сучасним, цікавим та інформативним, що е особливо важливим для навчання іноземної мови студентів технічних спеціальностей у вищих навчальних закладах. Тому, у статті проаналізовано автентичні відео як засоби, що покрашують навчання на заняттях із англійської мови технічного спрямування в технічних університетах. Зокрема, дається пояснення поняття «англійська мова технічного спрямування» (ESP) і його зв’язок iз поняттями «англійська як іноземна мова» (EFL) і «англійська мова для науки та техніки». У статті викладені основні особливості викладання ESP в технічних університетах. Крім того, пояснюеться важливість використання аудіовізуальних засобів (відеозаписів) на заняттях із англійської мови технічного спрямування на технічних фракультетах. Також, аналізуються переваги й можливі недоліки використання автентичних англомовних відео на заняттях із іноземної мови в технічних університетах. У роботі наведені приклади аудіовізуальних засобів. Серед них найбільш автентичними й найрізноманітнішими за тематикою і можливістю застосуванням на заняттях із англійської мови технічного спрямування $є$ фрільми та їх фрагменти, серіали, а також науково-популярні передачі. Викладач ESP (англійської мови технічного спрямування) може знайти в них необхідний фрагмент (або використати повністю) для покращення заняття за допомогою інформації, що відповідае спеціальності студентів і представлена найбільш ефективно для сприйняття - через слухову й зорову системи одночасно. Важливість автентичності навчальних матеріалів на заняттях ESP у технічних університетах також висвітлено. Після аналізу ролі автентичних англомовних відео на заняттях із англійської мови технічного спрямування описано деталі експериментальної перевірки досліджуваного питання, а також представлено результати експерименту зі студентами-інженерами третього курсу Інституту енергозбереження та енергоменеджменту Національного технічного університету України «Київський політехнічний інститут імені Ігоря Сікорського».
\end{abstract}

Ключові слова: автентичний, відео, засоби, англійська мова технічного спрямування, англійська мова як іноземна, заняття, навчання, студенти, фільм, кіно, технічний університет.

Tntroduction. With the constant development

1 of new technologies, they become ever-present in people's everyday lives. The sphere of education is not an exception. It has been believed among educators, both at school and university, that visuals add extra quality to lessons. However, not all visual aids are viewed by some English lecturers as $100 \%$ valuable. Among such are often mentioned authentic video records in English for Specific Purposes (ESP) lessons at technical universities. The main reason for that is considered limited time (number) of ESP lessons per week at technical faculties. Thus, authentic English videos are frequently being discarded due to English lecturers' subjective opinions that they are too time-consuming and hard-to-com- prehend for their students. The real role and influence of visuals, particularly authentic videos in English, on the studying process in the ESP class at a technical university requires further analysis.

Literature review. The use of videos, including films, and their influence on students' and learners' studying of different types of English have been investigated by researchers from various countries.

Gomathi, Geetha, and Raa [3] proved experimentally that authentic movies in English increased the first-year Indian undergraduate students' motivation to study English as a foreign language and, as a result, noticeably improved their vocabulary.

Merita Ismaili [5] presented in the article the confirmation of the beneficial nature of films for 
the work of students in the EFL class in terms of the enhancement of their listening comprehension and communication skills development. According to the study, motion pictures present English in a more natural way than texts in course books, play the role of visual context aids before reading, as well as attract students' attention.

Raniah Hassen Kabooha [7] and Rusma Kalra [8] share the above-mentioned thought of Ismaili (2013) on the importance and effectiveness of the integration of films in the EFL classrooms. The findings of Kabooha's (2016) study indicated that movies improved the students' language learning process and facilitated the development of their language skills. Kalra (2017) states that with films, in addition to their increased motivation and listening and speaking comprehension, the third-year Thai undergraduate students managed to learn how to produce speech in the close-to-authentic way as it is done by the native speakers of English.

Unresolved issues. Although worldwide researches were conducted to prove the hypothesis of the benefit of the use of videos in English as a Second Language (ESL) and English as a Foreign Language (EFL) classes at universities and schools, the issue of their extensive implementation in the English for Specific Purposes (ESP) lessons at technical faculties needs more in-depth analysis and experimental verification.

Aim. The goal of the current research is to analyse authentic videos as study-enhancing aids in ESP lessons at the technical university. Specifically, there are tasks to determine what is considered authentic videos, and whether they have a positive or negative influence on the ESP study of students living in Ukraine, i.e. non-English speaking country.

Analysis of authentic videos as study-enhancing aids. Before identifying the role of authentic English videos in teaching English for Spe- cific Purposes (ESP), it is necessary to clarify what is meant under ESP that students at technical universities study. ESP is, basically, a branch of English as a Foreign Language (EFL) that represents an ideal balance between research and practice, i.e. English teaching in academic studies or for specific professional and scientific purposes [2, p. 19; 6, p. 138].

The main features of ESP teaching at technical universities are [6, p. 139]:

1) relation to students specialty in terms of topics, disciplines, and activities;

2) aiming at meeting students' specified needs and the development of language skills (required for their future professions in the specialty field);

3) focusing on the English language (lexis and terminology, semantics, syntax, discourse, etc.) applicable to activities and situations characteristic of students' future professional field, hence, differentiating from general English by its concern with specialized language and practice.

According to Hutchinson and Waters' $[4$, p. 6] "Tree of ELT" (Fig. 1), students of technical universities study ESP in the form of English for Academic Purposes, and the engineering students, who took part in the experimental verification provided further in the article, study even more specific subcategory of ESP - English for Science and Technology (hereinafter - ESP).

Students of technical faculties are practically oriented in their study: theoretical materials in their professional disciplines, in most cases, are accompanied by visualizations in the forms of pictures, schemes, visual instructions, device and technology samples, etc. Therefore, such students should be provided with the same, if not even bigger, amount of visuals in the English lessons. The reason for that is that they may be able to learn, translate, and practice new English terminology and phrases concerning some innovative technologies and devices without a complete picture

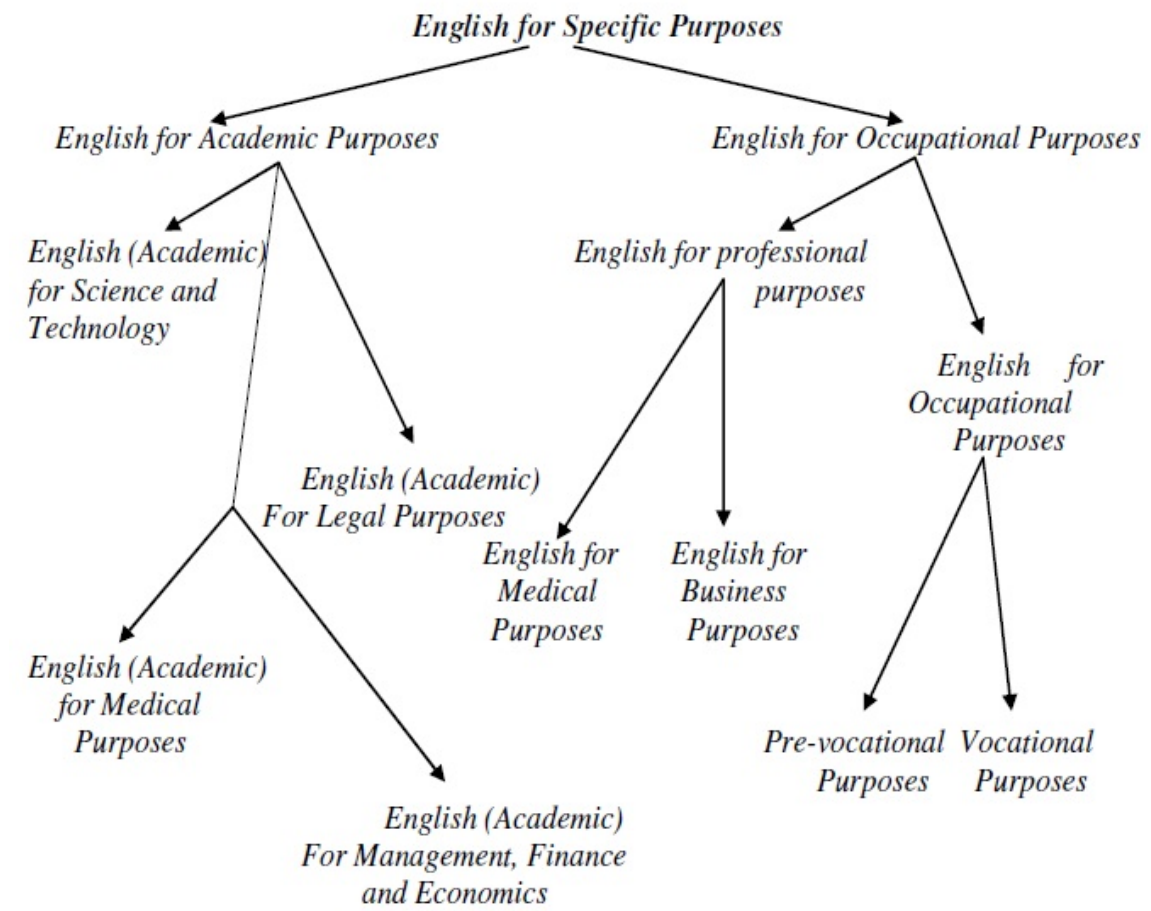

Fig. 1. Tree of ELT 
of what they are reading, talking or listening about. In this case, authentic videos in English come to the rescue, adding the missing element to the students' foreign language study - visual content.

The findings of Oxford and Crookal [10] showed that the combination of visual and audio aids used for teaching activates multiple parts of students' brains, and thus, they can process information more efficiently via both auditory and visual sensing systems. In addition to the improved study materials comprehension, students' ability of foreign vocabulary acquiring improves greatly and noticeably in the process of studying English with videos, as was verified by numerous researchers around the globe $[3 ; 5 ; 7 ; 8 ; 11]$.

Under the category of audiovisual media fall films and their fragments, programmes, series, as well as any other dubbed video records. Authentic videos, in their turn, are a type of audiovisual aids that are created for purposes other than pedagogical [9], primarily, for people for whom English is a native language. Consequently, authentic videos are always more valuable for teaching ESP (or EFL) than specially created for educational purposes, also known as 'adapted' ones. According to Sherman [11], the authenticity of study materials creates such incentive for students of technical specialties that no other type of educational aids can, as long as there is a special excitement in being able to comprehend the information on a video record, which corresponds to their specialty, created by and for native speakers of English.

Even though movies are rarely used by ESP lecturers at technical faculties, they are exactly the teaching aids that bear the most authenticity, context, and extralinguistic information (facial expressions, voice tone, gestures, etc.) - everything students require for successful communication in their future professional sphere.

With film/series fragments and programmes in English, ESP lecturers can ensure that their foreign language lessons meet the basic requirements and characteristics of ESP teaching, aforementioned in the current article, as well as get the following advantages in the class with students of technical faculties [1]:

1) authenticity of target language vocabulary and its natural use (presentation of "real" and modern English language with its constantly-developing and updating list of lexis and special terminology, which cannot be always found in textbooks);

2) visualization of various aspects of students' specialty (devices and technologies that they study both in specialty classes and in English lessons, as well as real examples of specialists of their field and their work situations);

3) maximization of students' attention to the studied material;

4) increase of students' productivity and its duration through the activation of two sensory systems at once - auditory and visual;

5) augmentation of technical students' motivation to study the foreign language.

Although the benefits of authentic videos use in ESP lessons are cogent, some possible negative aspects should be mentioned. Among them are:

1) authentic English videos may be hard to comprehend for students with insufficient levels of English language knowledge;

2) if the videos are presented in the lesson without a specific purpose (a task) before their watch- ing, the efficiency of such work in the ESP lesson declines greatly, and authentic videos in such a case may become just distraction;

3) if new terminology is not worked on with students of technical specialties prior to watching, the viewing may be complicated for them.

Experimental verification and results. To check whether authentic English videos affect the work (enhance the study) of technical students in ESP lessons positively, a 4-week experiment was conducted. 30 third-year engineering students were randomly selected and divided into 2 groups (experimental and control), 15 people in each, at the Institute of Energy Saving and Energy Management (IEE) of the National Technical University of Ukraine "Igor Sikorsky Kyiv Polytechnic Institute" in November 2018. It should be mentioned that the results of the pre-experiment test (which checked the students' vocabulary knowledge, both general and technical) of all 30 students were in the same mark range: 4-6 out of 10 .

During the experiment, both groups received the same teaching materials and tasks. The difference was in that Group 1 (experimental) was offered educational materials mostly in the form of authentic video clips in English (from Hollywood movies), thematically corresponding to the students' specialty - engineering, and Group 2 (control) received all the information as transcripts and texts. The main focus in tasks was made on the development of students' target language active and passive vocabulary and communicative skills.

The post-experimental test included the same lexis as had been provided in the pre-experimental test, as well as new terminology and general English words and phrases learnt during the time of the experiment.

According to the final results, Group 1 with the marks range $7-9$ out of 10 did much better than Group 2 with the marks range $6-7$ out of 10 . Consequently, the normal efficiency improvement ratio after a 4 -week experiment in Group 1 was 1.6, whereas in Group 2 it was 1.3. The students' vocabulary improved by almost two times in Group 1 and the progress remained practically the same in Group 2.

Moreover, in the post-test questionnaires, 95\% of the Group 1 students stated that they considered their ESP lessons with authentic videos interesting and motivating, and expressed the desire to watch the proposed films in full in English after the lessons and practice the learnt vocabulary henceforth. While only $75 \%$ of Group 2 students said that they felt the incentive to continue practicing newly learnt lexis after the class. This feedback shows the inspiring character of authentic videos in ESP lessons at technical university faculties.

The results of this year's experiment turned out to be positive, just like the outcomes of the last year's one with other $3^{\text {rd }}$-year engineering students, in which the influence of authentic English videos on the enhancement of technical students' memorization and subsequent recall of the English lexis was verified [12]. The coincidence of positive results of two experiments concerning the beneficial nature of authentic videos for ESP lessons at the technical university, which were conducted in different years and with different students of the same age, confirms undeniably the study-enhancing essence of authentic videos, in particular, film clips, in ESP lessons at technical universities. 
Thus, the influence of authentic English media on various aspects of ESP teaching and study has the potential for further examination.

Conclusions. The conducted research and analyses showed the following results:

1. English for Specific Purposes (ESP) is a branch of English as a Foreign Language (EFL) that represents a balance between research and practice, being English teaching in academic studies or for specific professional and scientific purposes.

2. Among the main features of ESP teaching at technical universities are: a) relation to students specialty (topics, disciplines, and activities); b) aiming at meeting students' specified needs and the development of language skills (required for their future professions in the specialty field); c) focusing on the English language applicable to activities and situations characteristic of students' future professional field (specialized language and practice).

3. Students of technical faculties are practically oriented, therefore, they should be provided with an abundant amount of visuals in the English lessons, and authentic videos in English add the missing element to the students' foreign language study - visual content.

4. Authentic videos are a type of audiovisual aids that are created for purposes other than pedagogical, primarily, for native speakers of English. Thus, authentic videos are always more valuable for teaching ESP than adapted ones (specially created for educational purposes) at technical universities.

5. Among popular and most useful audiovisual aids are films and their fragments, programmes, series, as well as any other dubbed video records. Movies bear the most authenticity, context, and extralinguistic information (facial expressions, voice tone, gestures, etc.) - everything students require for successful communication in their future professional sphere.

6. The advantages of using film/series fragments and programmes in English are: a) authenticity of target language vocabulary and its natural use; b) visualization of various aspects of students' specialty; c) maximization of students' attention; d) increase of students productivity and its duration; e) augmentation of technical students' motivation.

7. The combination of visual and audio aids used for teaching activates multiple parts of students' brains, and therefore, they can process information more efficiently via both auditory and visual sensing systems. In addition to the improved study materials comprehension, students' ability of foreign vocabulary acquiring improves greatly and noticeably in the process of studying English with videos. Moreover, the authenticity of study materials creates such incentive for students of technical specialties that no other type of educational aids can.

8. The possible negative aspects of authentic videos use in ESP lessons are: a) they may be hard to comprehend for students with insufficient levels of the English language knowledge; b) if the videos are presented in the lesson without a specific purpose (a task) before their watching, the efficiency of such work in the ESP lesson declines greatly; c) if new terminology is not worked on with students of technical specialties prior to watching, the viewing may be complicated for them.

9. The experimental verification of the enhancement of technical students' study with authentic English videos in ESP lessons showed that the experimental group students' vocabulary improved by almost two times due to being offered such educational materials as authentic video clips (from Hollywood movies) in English, thematically corresponding to their specialty - engineering, whereas the progress of the control group, which studied using only printed materials (video transcripts and texts), remained practically without changes. In addition to the practical results, $95 \%$ of the experimental group students stated that they considered their ESP lessons with authentic videos interesting and motivating, and expressed the desire to watch the proposed films in full in English after the lessons and practice the learnt vocabulary henceforth. While only $75 \%$ of the control group students said that they felt the incentive to continue practicing newly learnt lexis outside the class.

\section{References:}

1. Barekat B. (2014). The Effect of Authentic and Inauthentic Materials in Cultural Awareness Training on EFL Learners' Listening Comprehension. Theory and Practice in Language Studies. 4(5), 1058-1065.

2. Dudley-Evans A., St. John A.M. (1998). Developments in English for Specific Purposes: A multi-disciplinary approach. Cambridge : Cambridge University Press.

3. Gomathi B.S., Geetha T.S., Raa M.R.R. (2017). A Study of Vocabulary Learning Using Film as a Media A Case Study of The Under Graduate Engineering Students. Veda's Journal of English Language and LiteratureJOELL. 4(4), 111-117.

4. Hutchinson T., Waters A. (1987). English for specific purposes: a Learning-centered Approach. Cambridge : Cambridge University Press.

5. Ismaili M. (2013). The Effectiveness of Using Movies in the EFL Classroom - A Study Conducted at South East European University. Academic Journal of Interdisciplinary Studies. 2(4), 121-132.

6. Javid, C.Z. (2013). English for Specific Purposes: Its Definition, Characteristics, Scope and Purpose. European Journal of Scientific Research. 112(1), 138-151.

7. Kabooha R.H. (2016). Using Movies in EFL Classrooms: A Study Conducted at the English Language Institute (ELI), King Abdul-Aziz University. English Language Teaching. 9(3), 248-257.

8. Kalra R. (2017). The Effectiveness of Using Films in the EFL Classroom: A Case Study Conducted at an International University in Thailand. Arab World English Journal. 8(3), 289-301.

9. Nunan D. (1988). The Learner-Centered Curriculum. Cambridge : Cambridge University Press.

10. Oxford R., Crookall D. (1990). Vocabulary learning: A critical analysis of techniques. TESL Canada Journal. 7(2), 9-30.

11. Sherman J. (2003). Using Authentic Film in the Language Classroom. Cambridge : Cambridge University Press.

12. Shevchenko M. (2018). Analysis of the Influence of Authentic English Videos on Technical Students' Memorization and Subsequent Recall of the English Lexis. Science and Education a New Dimension. Pedagogy and Psychology. VI (65), Issue: $155,49-53$. 